\title{
PERLINDUNGAN HUKUM BAGI PASIEN SELAKU KONSUMEN TERHADAP TINDAKAN MALPRAKTIK DI BIDANG KESEHATAN
}

Oleh :

\author{
Sutono Widjaja \\ Email : sutono_w@yaahoo.com \\ Universitas Narotama Surabaya
}

\begin{abstract}
Abstrak
Malpraktik pada dasarnya adalah tindakan tenaga profesional yang bertentangan dengan SOP, kode etik, dan undang-undang yang berlaku, baik disengaja maupun akibat kelalaian yang mengakibatkan kerugian atau kematian pada orang lain.Disisi lain, dalam pelaksanaan tindakan pelayanan kesehatan, tenaga medis, yaitu dokter maupun perawat tidak menutup kemungkinan terjadi suatu kesalahan ataupun kelalaian. Kesalahan ataupun kelalaian yang dilakukan dokter dalam melaksanakan tugas profesinya dapat berakibat fatal baik terhadap badan maupun jiwa dari pasiennya (dalam istilah medis/hukum kejadian ini disebut malpraktik) dan hal ini tentu saja sangat merugikan bagi pihak pasien sebagai korban malpraktik. Sebagai korban malpraktik yang dirugikan, sudah tentu pasien akan menuntut apa yang menjadi haknya. Pasien yang menjadi korban malpraktik akan menuntut ganti rugi atau meminta pertanggungjawaban dari dokter yang bersangkutan. Tuntutan tersebut dapat berupa tuntutan perdata, yaitu ganti rugi, tuntutan secara pidana, yaitu hukuman penjara bagi pelaku malpraktik.
\end{abstract}

Kata kunci : malpraktik, pasien, kesehatan

\begin{abstract}
Malpractice cases are a crime that is very common in Indonesia. Malpractice is basically the actions of professionals who contravene SOPs, codes of ethics, and applicable laws, whether intentional or as a result of negligence resulting in loss or death to others. On the other hand, in the implementation of health services, medical personnel, namely doctors and nurses do not rule out the possibility of an error or negligence. Errors or negligence by doctors in carrying out their professional duties can be fatal both to the body and soul of the patient (in medical/legal terms this incident is called malpractice) and this is of course very detrimental to the patient as a victim of malpractice. As a victim of malpractice that is harmed, of course the patient will demand what is his right. Patients who are victims of malpractice will demand compensation or ask for accountability from the doctor concerned. These demands can be in the form of civil claims, namely compensation, criminal charges, namely imprisonment for perpetrators of malpractice.
\end{abstract}

Keywords : malpractice, patient, health 


\section{PENDAHULUAN}

\subsection{Latar Belakang}

Ada berbagai faktor yang menjadi latar belakang munculnya gugatan-gugatan malpraktik tersebut dan semuanya berangkat dari kerugian psikis dan fisik korban. Mulai dari kesalahan diagnosis dan pada gilirannya mengimbas pada kesalahan terapi hingga pada kelalaian dokter pasca operasi pembedahan pada pasien (alat bedah tertinggal didalam bagian tubuh), dan faktor- faktor lainnya. ${ }^{1}$

Lepas dari fenomena tersebut, ada yang mempertanyakan apakah kasus-kasus itu terkategori malpraktik medik ataukah sekedar kelalaian (human error) dari sang dokter.Untuk diketahui, sejauh ini di negara kita belum ada ketentuan hukum ihwal standar profesi kedokteran yang bisa mengatur kesalahan profesi. Sebenarnya kasus malpraktik ini bukanlah barang baru. Sejak bertahun-tahun yang lalu, kasus ini cukup akrab di Indonesia.

Kasus malpraktik merupakan tindak pidana yang sangat sering terjadi di Indonesia. Malpraktik pada dasarnya adalah tindakan tenaga profesional yang bertentangan dengan SOP, kode etik, dan undangundang yang berlaku, baik disengaja maupun akibat kelalaian yang mengakibat-

\footnotetext{
1 Alexandra Ide, 2012, Etika dan Hukum dalam Pelayanan Kesehatan, Grasia Book Publisher, Yogyakarta, hlm. 49
}

kan kerugian atau kematian pada orang lain.

Disisi lain, dalam pelaksanaan tindakan pelayanan kesehatan, tenaga medis, yaitu dokter maupun perawat tidak menutup kemungkinan terjadi suatu kesalahan ataupun kelalaian. Kesalahan ataupun kelalaian yang dilakukan dokter dalam melaksanakan tugas profesinya dapat berakibat fatal baik terhadap badan maupun jiwa dari pasiennya (dalam istilah medis/hukum kejadian ini disebut malpraktik) dan hal ini tentu saja sangat merugikan bagi pihak pasien sebagai korbanmalpraktik. $^{2}$

Sebagai korban malpraktik yang dirugikan, sudah tentu pasien akan menuntut apa yang menjadi haknya. Pasien yang menjadi korban malpraktik akan menuntut ganti rugi atau meminta pertanggungjawaban dari dokter yang bersangkutan. Tuntutan tersebut dapat berupa tuntutan perdata, yaitu ganti rugi, tuntutan secara pidana, yaitu hukuman penjara bagi pelaku malpraktik.

Berlakunya Undang-Undang No. 36 Tahun 2009 tentang Kesehatan menggantikan Undang-Undang No. 23 Tahun 1992, Undang-Undang No. 8 Tahun 1999 tentang Perlindungan Konsumen, UndangUndang No. 29 Tahun 2004 tentang Praktik Kedokteran dan peraturan lainnya yang berkaitan baik langsung maupun tidak langsung dengan pemeliharaan kesehatan atau

\footnotetext{
2 Wila Chandrawila Supriadi, 2001, Hukum Kedokteran, Mandar Maju, Bandung, hlm. 35
} 
pelayanan kesehatan dan penerapannya dapat melindungi korban malpraktik berkaitan dengan hak-hak yang dimiliki oleh korban, sehingga apa yang menjadi tujuan dari hukum, yaitu kepastian, keadilan, dan kemanfaatan benar-benar dapat dilaksanakan sepenuhnya.

Lahirnya Hukum Kedokteran yaitu Undang-Undang tentang Praktik Kedokteran No. 29 Tahun 2004. LN No. 116 Tahun 2004, TLN No. 4431 yang merupakan bagian dari Hukum Kesehatan, ditujukan agar hak-hak pasien lebih dapat dilindungi oleh undang-undang. Hukum Kedokteran tersebut bertumpu pada dua hak asasi manusia, yaitu hak atas pemeliharaan kesehatan (the right to healthcare) dan hak untuk menentukan nasib sendiri (the right to self- determination atau zelf-bechikkingsrecht)..$^{3}$

\subsection{Perumusan Masalah}

Berdasarkan latar belakang yang telah dipaparkan diatas, maka permasalahan yang akan diteliti dapat dirumuskan sebagai berikut :

1. Apa bentuk perlindungan hukum bagi pasien sebagai pengguna jasa kesehatan?

2. Bagaimana tindakan medis yang dilakukan dokter dapat dikatakan dengan malpraktik?

\footnotetext{
${ }^{3}$ Hermien Hadiati Koeswadji, 1992, Beberapa Permasalahan Hukum dan Medik, (PT Citra Aditya Bakti, Bandung, hlm. 6.
}

3. Bagaimana penyelesaian sengketa penyelesaian malpraktik antara pasien dengan dokter?

\section{METODE PENELITIAN}

Tulisan ini menggunakan metode penelitian hukum normatif, yaitu meneliti hukum dari perspektif internal dengan objek penelitiannya adalah norma hukum. Dengan kata lain penelitian hukum yang meletakkan hukum sebagai sebuah bangunan sistem norma. Sistem norma yang dimaksud adalah mengenai asas- asas, norma, kaidah dari peraturan perundangan, putusan pengadilan, perjanjian serta doktrin (ajaran). ${ }^{4}$

Pendekatan yang digunakan adalah pendekatan perundang-undangan dan pendekatan konseptual. Pendekatan perundangundangan atau statute approach digunakan jika permasalahan penelitiannya mempermasalahkan konflik norma yang terjadi secara vertikal maupun horizontal. Misalnya norma yang berada pada sebuah peraturan perundang-undangan yang bersifat khusus atau umum, ataukah berada pada yang lebih tinggi atau lebih rendah, dan berada pada yang lama atau yang baru.

Pendekatan konseptual atau conceptual approach beranjak dari pandangan-

4 I Made Pasek Diantha, 2016, Metodolog iPenelitian Hukum Normatif dalam Justifikasi Teori Hukum (Jakarta: Prenada Media Grup). hlm12 
pandangan dan doktrin-doktrin yang berkembang di dalam ilmu hukum, sehingga dapat menemukan ide-ide yang melahirkan pengertian-pengertian hukum, konsepkonsep hukum, dan asas-asas hukum yang relevan dengan isu yang dihadapi. ${ }^{5}$

\section{PEMBAHASAN}

\subsection{Bentuk Perlindungan Pasien Sebagai}

\section{Konsumen Jasa Kesehatan}

Perlindungan Hukum merupakan unsur yang harus ada dalam suatu negara. Setiap pembentukan negara pasti di dalamnya ada hukum untuk mengatur warga negaranya. Dalam suatu negara, pasti terjadi hubungan antara negara dengan warga negaranya. Hukum adalah suatu peraturan yang memaksa, akan tetapi tidak untuk memaksakan sesuatu pada seseorang melainkan untuk melindungi kepentingankepentingan manusia. Hal ini disebabkan karena kepentingan itu kerap kali diancam atau dilanggar oleh pihak tertentu sehingga hukum perlu mengamankannya dan bila perlu memaksa. ${ }^{6}$

Menurut R. Soeroso, "Hukum adalah himpunan yang dibuat oleh yang berwenang dengan tujuan untuk mengatur tata kehidupan bermasyarakat yang mempunyai ciri memerintah dan melanggar serta

\footnotetext{
${ }^{5}$ Ibid, hlm. 159

6 R.Soeroso, 1992, Pengantar Ilmu Hukum, Jakarta:Sinar Grafika,hlm.24
}

mempunyai sifat memaksa dengan menjatuhkan sanksi hukuman bagi yang melanggarnya". 7 Perlindungan hukum terdiri dari 2 (dua) suku kata yaitu perlindungan dan hukum artinya perlindungan menurut undang-undang yang berlaku. Perlindungan hukum merupakan sarana untuk mewujudkan dan mempertahankan keadilan yang menjadi jiwa dan tujuan dari hukum.

Tujuan perlindungan hukum tentunya untuk memberikan rasa aman baik secara fisik maupun secara mental dari ancaman, gangguan teror atau kekerasan dari pihak manapun berdasarkan asas negara hukum. Hubungan hukum yang dilakukan antara pelaku hukum dapat memperoleh kepastian hukum sehingga setiap hubungan hukum dapat menciptakan kedamaian, keadilan, dan juga kemanfaatan kepada masingmasing pihak.Tujuan perlindungan hukum dilakukan agar para pelaku hukum atau masing-masing pihak dapat saling percaya dan saling memiliki itikad baik, agar tidak ada hak-hak dari masing-masing pihak yang dilanggar satu sama lain. ${ }^{8}$ Perlindungan hukum preventif sangat besar artinya bagi tindakan pemerintahan yang didasarkan pada kebebasan bertindak karena dengan adanya perlindungan hukum preventif pemerintah terdorong untuk bersikap hati-

7 Sumber: http:// www.prakoso.com : pengertianperlindungan-hukum. Html, (diakses pada 6 April 2019 pukul: $19.00 \mathrm{WIB})$

8 Ridwan Khairandy,2003, Itikad Baik dalam Kebebasan Berkontrak,Fakultas Hukum Universitas Indonesia, Jakarta. hlm. 217. 
hati dalam mengambil keputusan yang didasarkan pada diskresi. Belum ada peraturan khusus yang mengatur lebih jauh tentang perlindungan hukum tersebut di Indonesia. Patut dicatat bahwa upaya untuk mendapatkan perlindungan hukum tentunya yang diinginkan manusia adalah ketertiban dan keteraturan antara nilai dasar dari hukum yaitu adanya kepastian, kemanfaatan, serta keadilan hukum, meskipun pada umumnya dalam praktek ketiga nilai dasar tersebut bersitegang, namun haruslah diusahakan untuk ketiga nilai dasar tersebut bersamaan.

Dalam Undang-Undang Nomor 8 Tahun 1999 tentang Perlindungan Konsumen tidak diatur dengan jelas mengenai pasien atau korban malpraktik, tetapi pasien atau korban malpraktik dalam hal ini juga merupakan seorang konsumen. Selain itu, Keputusan Menteri Kesehatan RI No.756/ MEN.KES/SK/VI/2004 tentang Persiapan Liberalisasi Perdagangan dan Jasa di Bidang Kesehatan, menyatakan bahwa jasa layanan kesehatan termasuk bisnis. Bahkan, World Trade Organisation (WTO) memasukkan Rumah Sakit (RS), dokter, bidan maupun perawat sebagai pelaku usaha.

Perlindungan hukum terhadap korban malpraktik kedokteran sebagai konsumen dapat dilihat dalam ketentuan Pasal 19 ayat (1) UU Perlindungan Konsumen yang selengkapnya dinyatakan bahwa "Pelaku usaha bertanggung jawab untuk memberi- kan ganti rugi atas kerusakan, pencemaran, dan/atau kerugian konsumen akibat mengkonsumsi barang dan/atau jasa yang dihasilkan atau diperdagangkan."

Berdasarkan ketentuan Pasal 19 ayat (1) UU Perlindungan Konsumen, kerugian yang diderita korban malpraktik sebagai konsumen jasa akibat tindakan medis yang dilakukan oleh dokter sebagi pelaku usaha jasa dapat dituntut dengan sejumlah ganti rugi.

Ganti kerugian yang dapat dimintakan oleh korban malpraktik menurut Pasal 19 ayat (2) UU Perlindungan Konsumen dapat berupa pengembalian uang penggantian barang dan/atau jasa yang sejenis atau setara nilainya, atau perawatan kesehatan dan/atau pemberian santunan yang sesuai dengan ketentuan peraturan perundangundangan yang berlaku.

Berdasarkan uraian diatas, dapat disimpulkan bahwa bentuk perlindungan hukum terhadap korban malpraktik yang diatur dalam Undang-Undang No. 8 Tahun 1999 Tentang Perlindungan Konsumen, yaitu berupa pengaturan pertanggungjawaban dokter untuk memberikan ganti rugi kepada korban malpraktik selaku konsumen, sebagai akibat adanya kesalahan atau kelalaian dalam pelayanan kesehatannya atau malpraktik yang dilakukan oleh dokter selaku pelaku usaha serta pengaturan pemberlakuan ketentuan hukum pidana yang disertai dengan pidana tambahan. 
Pasien atau pesakit adalah seseorang yang menerima perawatan medis. Kata pasien dari bahasa Indonesia analog dengan kata patient dari bahasa Inggris. Patient diturunkan dari bahasa Latin yaitu patiens yang memiliki kesamaan arti dengan kata kerja pati yang artinya "menderita". Sedangkan menurut Kamus Besar Bahasa Indonesia, pasien merupakan adalah sakit (yang dirawat dokter), penderita (sakit). ${ }^{9}$

Malapraktik, berasal dari kata "mala" artinya salah atau tidak semestinya, sedangkan praktik adalah proses penanganan kasus (pasien) dari seorang profesional yang sesuai dengan prosedur kerja yang telah ditentukan oleh kelompok profesinya. Sehingga malapraktik dapat diartikan melakukan tindakan atau praktik yang salah atau yang menyimpang dari ketentuan atau prosedur yang baku(benar).

Hak dan kewajiban pasien selaku konsumen jasa pelayanan kesehatan didasari dengan adanya hubungan hukum antara pasien dengan pemberi jasa pelayanan kesehatan yang dalam hal ini adalah dokter. Hubungan antara pasien dengan dokter maupun rumah sakit adalah apa yang dikenal sebagai perikatan (verbintenis). Dasar dari perikatan yang berbentuk antara dokter pasien biasanya adalah perjanjian, tetapi dapat saja terbentuk perikatan ber-

\footnotetext{
${ }^{9}$ Pusat Bahasa Departemen Pendidikan Nasional,http://bahasa.kemdiknas.go.id/kbbi/index.p hpdiakses pada tanggal 13 Januari 2020
}

dasarkan undang- undang. ${ }^{10}$

Perjanjian yang dikenal dalam bidang pelayanan kesehatan yaitu perjanjian (transaksi) terapeutik.Transaksi terapeutik adalah perjanjian antara dokter dengan pasien, berupa hubungan hukum yang melahirkan hak dan kewajiban bagi kedua bela pihak.Objek dari perjanjian ini adalah berupa upaya atau terapi untuk penyembuhan pasien. Sebagaimana umumnya suatu perikatan, dalam transaksi teraupetik juga terdapat para pihak yang mengikatkan diri dalam suatu perikatan atau perjanjian, yakni dokter sebagai pihak yang melaksanakan atau memberikan pelayanan medis dan pasien sebagai pihak yang menerima pelayanan medis.

Dalam pengertian hukum, hak adalah kepentingan hukum yang dilindungi oleh hukum. Kepentingan sendiri berarti tuntutan yang diharapkan untuk dipenuhi. Sehingga dapat dikatakan bahwa hak adalah suatu tuntutan yang pemenuhannya dilindungi oleh hukum. ${ }^{11}$ Malpraktik kedokteran pidana hanya terjadi pada tindak pidana materiil (KUHP), yaitu suatu tindak pidana yang melarang menimbulkan akibat tertentu yang diancam dengan sanksi berupa pidana. Timbulnya akibat, menjadi syarat selesainya tindak pidana. Adapun akibat yang

\footnotetext{
${ }^{10}$ Wila Chandrawila Supriadi, , Hukum Kedokteran, Mandar Maju, Bandung, 2001, hal. 29.

${ }^{11}$ Sudikno Martokusumo, 1999, Mengenai Hukum : Suatu Pengantar, Liberty, Yogyakarta, hal.24.
} 
menjadi unsur malpraktik kedokteran pidana adalah kematian, luka berat, rasa sakit, atau luka yang mendatangkan penyakit, atau luka yang menghambat tugas dan mata pencaharian.

Dalam hal adanya malpraktik kedokteran pidana (crime malpractive), pertanggungjawaban pidana itu harus dapat dibuktikan tentang adanya kesalahan profesional, misalnya kesalahan diagnosis atau kesalahan cara pengobatan atau perawa$\tan ^{12}$

Dalam hal korban malpraktik kedokteran pidana mengalami luka berat, atau luka yang mendatangkan penyakit, atau luka yang menghambat tugas dan mata pencaharian, ketentuan pidananya diatur pada Pasal 360 ayat (1) yang berbunyi: "Barang siapa karena kesalahannya (kealpaannya) menyebabkan orang lain mendapat luka-luka berat, diancam dengan pidana penjara paling lama lima tahun atau pidana kurungan paling lama satu tahun”. Ayat (2): "Barang siapa karena kesalahannya (kealpaannya) menyebabkan orang lain luka-luka sedemikian rupa sehingga timbul penyakit atau halangan menjalankan pekerjaan, jabatan atau pecaharian selama waktu tertentu, diancam dengan pidana penjara paling lama sembilan bulan atau pidana kurungan paling lamaenam bulan

\footnotetext{
${ }^{12}$ Y.A. Triana Ohoiwutun, 2007, Bunga Rampai Hukum Kedokteran Edisi I, Banyu Media Publishing, Malang, hlm. 5.
}

atau pidana denda paling tinggi empat ribu lima ratusrupiah.

\subsection{Tindakan Medis Yang Dilakukan Oleh Dokter Yang Dapat Dikata- kan Tindakan Malpraktik}

Untuk dapat menilai dan membuktikan suatu perbuatan (tindakan medis) termasuk kategori malpraktik atau tidak, menurut Hubert W. Smith tindakan malpraktik meliputi 4D, yaitu : ${ }^{13}$

a. adanya kewajiban (duty), dalam unsur ini tidak ada kelalaian jika tidak terdapat kewajiban, oleh karena itu unsur yang pertama ini menyatakan harus ada hubungan hukum antara pasien dengan dokter/rumahsakit.

b. adanya penyimpangan dalam pelaksanaan tugas (dereliction), yaitu dokter dalam melakukan kewajiban terhadap pasien melakukan tindakan penyimpangan dari standar profesitersebut.

c. penyimpangan akan mengakibatkan kerusakan (direct caution), dalam unsur ini terdapat hubungan kausal yang jelas antara tindakan medik yang dilakukan dokter dengan kerugian yang dialamipasien.

d. sang dokter akan menyebabkan kerusakan (damage), yaitu bahwa tindakan medik yang dilakukan dokter merupakan

\footnotetext{
${ }^{13}$ Hubert W. Smith, 2008, Kesalahan Dokter atau Tindakan Malpraktik, Penerbit Buku Kedokteran EGC, Jakarta, hlm. 40.
} 
penyebab langsung timbulnya kerugian terhadappasien.

Yang termasuk kriteria tindakan medis yang bersifat malpraktik, yaitu:

a. Adanya pengaturan terhadaphukum

b. Adanya hubungan hukum parapihak

c. Adanya pelanggaran hak dankewajiban

d. Adanya akibat hukum yangditimbulkan.

Suatu tindakan medis yang dilakukan oleh dokter, dapat digolongan sebagai tindakan medis yang bersifat malpraktik jika tindakan medis tersebut memenuhi bentuk dari wanprestasi (prestasi yang buruk), dan/atau memenuhi unsur-unsur perbuatan melawan hukum dan tindakan medis tersebut mengakibatkan kerugian bagi pasien atau korban malpraktik baik fisik maupun jiwanya bisa dilakukan tuntutan baik berupa ganti kerugian maupun pidana penjara.

Kasus hukum dalam pelayanan medis umumnya terjadi di rumah sakit dimana tenaga kesehatan bekerja. Rumah sakit merupakan suatu yang pada pokoknya dapat dikelompokkan menjadi:

a. Pelayanan medis dalam arti luas yang menyangkut kegiatan promotif, preventif, kuratif dan rehabilitatif.

b. Pendidikan dan latihan tenagamedis.

c. Penelitian dan pengembangan ilmu kedokteran.
Pertanggungjawaban hukum rumah sakit, dalam hal ini badan hukum yang memilikinya bisa dituntut atas kerugian yang terjadi, bisa secara:

a. Langsung sebagai pihak, pada suatu perjanjian bila ada wanprestasi,atau

b. Tidak langsung sebagai majikan bila karyawannya dalam pengertian peraturan perundang-undangan melakukan perbuatan melanggarhukum.

Wujud ganti kerugian tersebut bertujuan untuk memperbaiki keadaan, dan dari pengganti kerugian kebanyakan besar berupa sejumlah uang.Pengganti kerugian tersebut harus dinilai menurut kemampuan maupun kedudukan dari kedua belah pihak dan harus pula disesuaikan.

Dalam hal pertanggung jawaban atas pelayanan medis, yang mana pihak pasien merasa dirugikan maka perlu untuk diketahui siapa yang terkait didalam tenaga medis tersebut. Tenaga Medis yang dimaksud adalah dokter, yang bekerjasama dengan tenaga profesional lain didalam menyelenggarakan dan memberikan pelayanan medis kepada masyarakat ataupasien.

Terhadap tenaga kesehatan khususnya yang bekerja di rumah sakit, ada dua tenaga yaitu: tenaga dari PNS (Pegawai Negeri Sipil) dan Swasta. Dalam melaksanakan tugas profesinya, baik tenaga dari PNS ataupun swasta mempunyai perbedaan dalam tanggung jawab. Terhadap tenaga 
kesehatan (dokter) dari PNS yang melakukan kesalahan/kelalaian dalam tindakan medis, biasanya dokter tersebut diberikan sanksi berupa pemindahan kerja ke instansi kesehatan lain atau pemberhentian sementara, sedangkan terhadap dokter yang swasta, dalam hal melakukan kesalahan atau kelalaian biasanya sanksi yang dijatuhkan berupa diberhentikan oleh rumah sakit tempat ia bekerja, dan akibat dari kesalahan dokter atau paramedis lain yang menyebabkan kerugian terhadap pasien akan menjadi beban bagi pihak rumah sakit.

Tanggung jawab dilihat dari segi hukum perdata mengandung beberapa aspek, yaitu dapat ditimbulkan karena "wanprestasi", karena perbuatan melanggar hukum, dapat juga karena karena kurang hati-hatinya mengakibatkan matinya orang dan juga karena kurang hati-hatinya yang menyebabkan cacat badan. Akibat perbuatan yang mengakibatkan kerugian tersebut terbawa oleh karena sifat dari perjanjian yang terjadi antara dokter dengan pasien merupakan suatu perjanjian yang disebut “inspannings verbintenis".Suatu perjanjian yang harus dilaksanakan dengan teliti dan penuh hati-hati (inspanning) dan hubungan dokter dengan pasien ada juga dengan perikatan hasil, atau yang dikenal dengan "resultaat verbintenis".

Sehingga berdasarkan hal-hal yang telah disebutkan didepan, maka perlu kiranya kepentingan pasien juga diperhatikan dengan mengadakan perlindungan terhadap korban yang menderita kerugian dari kesalahan tenaga medis dengan mempercepat proses untuk mendapatkan ganti rugi.

\subsection{Penyelesaian Sengekta Malpraktik Antara Pasien Dengan Dokter}

Sistem hukum Indonesia yang salah satu komponennya adalah hukum substantif, diantaranya hukum pidana, hukum perdata dan hukum adminstrasi tidak mengenal bangunan hukum "malpraktik". Kalau ditinjau dari budaya hukum Indonesia, malpraktek merupakan sesuatu yang asing, karena batasan pengertian malpraktek yang diketahui dan dikenal oleh kalangan medis (kedokteran) dan hukum berasal dari alam pemikiran barat.

Permasalahan malpraktik di Indonesia dapat ditempuh melalui dua jalur, yaitu jalur litigasi (peradilan) dan jalur non litigasi (diluar peradilan).

a. Melalui Jalur Litigasi

Sebagaimana yang diatur dalam Pasal 45 ayat (1) Undang-Undang tentang Perlindungan Konsumen yaitu setiap konsumen yang dirugikan dapat menggugat pelaku usaha melalui lembaga yang bertugas menyelesaikan sengketa antara konsumen dan pelaku usaha yang bertugas menyelesaikan sengketa antara konsumen dan pelaku usaha atau melaluiperadilan yang berbeda di lingkungan peradilan umum. 
Pasal 45 ayat (3) mengatur penyelesaian sengketa di luar pengadilan tidak menghilangkan tanggung jawab pidana sebagaimana diatur dalam undang- undang. Jelas seharusnya bukan hanya tanggung jawab pidana yang tetap dibuka kesempatannya untuk diperkarakan, melainkan juga tanggung jawab lainnya, misalnya di bidang administrasi negara. Konsumen yang dirugikan haknya, tidak hanya diwakilkan oleh jaksa dalmpenuntutan di peradilan umum untuk kasus pidana, tetapi ia sendiri dapat juga menggugat pihak lain di lingkungan peradilan tata usaha negara jika terdapat sengketa administratif didalamnya.

b. Melalui Jalur Non Litigasi

Di Indonesia, penyelesaian kasus malpraktek medik mengacu pada Pasal 66 Undang-Undang Nomor 29 Tahun 2004 tentang Praktek Kedokteran mengatur pasien atau keluarga pasien yang merasa dirugikan akibat praktek kedokteran yang mereka anggap tidak tepat dapat mengadukan kasusnya melalui Majelis Kehormatan Disiplin Kedokteran Indonesia (MKDKI), yang merupakan jalur non litigasi. Selain melalui jalur non litigasi, pasien atau keluarga pasien yang menduga telah terjadi malpraktek atas diri pasien tidak tertutup kemungkinan untuksekaligus menempuh jalur litigasi, yaitu melalui jalur perdata atau pidana. $^{14}$

Kewenangan MKDKI diatur dalam Pasal 67, dimana MKDKI berwenang untuk memeriksa dan memberikan keputusan terhadap pengaduan yang berkaitan dengan disiplin dokter dan dokter gigi.Lembaga ini merupakan lembaga otonom dari Konsil Kedokteran Indonesia yang dalam menjalankan tugasnya bersifat independen. Sanksi yang diberikan dapat berupa pemberian peringatan tertulis, rekomendasi pencabutan surat tanda registrasi atau surat izin praktek dan/atau kewajiban mengikuti pendidikan atau pelatihan di institusi pendidikan atau kedokterangigi.

Apabila dalam pemeriksaan ditemukan pelanggaran etika, MKDKI meneruskan pengaduan pada organisasi profesi (Ikatan Dokter Indonesia/IDI atau Perhimpunan Dokter Gigi Indonesia/PDGI). Kasus tersebut kemudian akan ditangani oleh Majelis Kehormatan Etik Kedokteran Indonesia (MKEK) IDI atau MKEK Gigi adalah suatu badan peradilan profesi, yang bertugas mengadili anggota ikatan profesi itu sendiri. Namun apabila suatu kasus diduga malpraktek medik diadukan oleh masyarakat dan didapati pelanggaran hukum, MKDKI akanmenganjurkansupaya kasus itu langsung dibawa ke sidang pengadilan untuk diperiksa. Oleh karena Undang-Undang tentang Praktek Kedok-

\footnotetext{
${ }^{14}$ Ari Yunanto dan Helmi, 2010, Hukum Pidana Malpraktik Medik, CV.Andi, Yogyakarta, hlm.87.
} 
teran hanya fokus pada disiplin kedokteran saja, sehingga masalah gugatan perdata atau pidana diserahkan kepada peradilan umum dengan memakai saksi ahli (expert witness testimonum) apabila diperlukan sebagaimana lazimnya juga di luarnegeri.

Untuk mengatasi kerumitan proses peradilan, Undang-Undang tentang Perlindungan Konsumen memberi jalan alternatif dengan menyediakan penyelesaian sengketa diluar pengadilan. Pasal 45 ayat (4) mengatur, jika telah dipilih upaya penyelesaian sengketa konsumen diluar pengadilan, gugatan melalui pengadilan hanya dapat ditempuh jika upaya itu dinyatakan tidak berhasil oleh salah satu pihak atau oleh para pihak yang bersengketa. Ini berarti penyelesaian pengadilan pun tetap terbuka setelah para pihak gagal menyelesaikan sengketa mereka di luar pengadilan.

Tafsir yang lebih jauh dari ketentuan pasal tersebut, bahwa :

a. penyelesaian diluar pengadilan merupakan upaya perdamaian diantara pihak yang bersengketa ;

b. penyelesaian diluar pengadilan dapat dilakukan melalui suatubadan independen seperti Badan Penyelesaian Sengketa Konsumen (BPSK).

c. Jika penyelesaian melalui BPSK, maka salah satu pihak tidak dapat menghentikan perkaranya di tengah jalan, sebelum BPSK menjatuhkan putusan. Artinya bahwa mereka terikat untuk menenmpuh proses penyelesaian sampai dengan penjatuhan putusan.

\section{KESIMPULAN}

1. Malpraktik kedokteran pidana hanya terjadi pada tindak pidana materiil (KUHP), yaitu suatu tindak pidana yang melarang menimbulkan akibat tertentu yang diancam dengan sanksi berupa pidana. Timbulnya akibat, menjadi syarat selesainya tindak pidana. Adapun akibat yang menjadi unsur malpraktik kedokteran pidana adalah kematian, luka berat, rasa sakit, atau luka yang mendatangkan penyakit, atau luka yang menghambat tugas dan mata pencaharian.Dalam hal adanya malpraktik kedokteran pidana (crime malpractive), pertanggungjawaban pidana itu harus dapat dibuktikan tentang adanya kesalahan profesional, misalnya kesalahan diagnosis atau kesalahan cara pengobatan atau perawatan. Ganti kerugian yang dapat dimintakan oleh korban malpraktik menurut Pasal 19 ayat (2) UU Perlindungan Konsumen dapat berupa pengembalian uang penggantian barang dan/atau jasa yang sejenis atau setara nilainya, atau perawatan kesehatan dan/atau pemberian santunan yang sesuai dengan ketentuan peraturan perundang-undangan yang berlaku. 
2. Suatu tindakan medis yang dilakukan oleh dokter, dapat digolongan sebagai tindakan medis yang bersifat malpraktik jika tindakan medis tersebut memenuhi bentuk dari wanprestasi (prestasi yang buruk), dan/atau memenuhi unsur-unsur perbuatan melawan hukum dan tindakan medis tersebut mengakibatkan kerugian bagi pasien atau korban malpraktik baik fisik maupun jiwanya bisa dilakukan tuntutan baik berupa ganti kerugian maupun pidana penjara. Dalam hal pertanggungjawaban atas pelayanan medis, yang mana pihak pasien merasa dirugikan maka perlu untuk diketahui siapa yang terkait didalam tenaga medis tersebut. Tenaga Medis yang dimaksud adalah dokter, yang bekerjasama dengan tenaga profesional lain didalam menyelenggarakan dan memberikan pelayanan medis kepada masyarakat ataupasien.
3. Penyelesaian sengketa diluar pengadilan tidak menghilangkan tanggung jawab pidana sebagaimana diatur dalam undang-undang. Jelas seharusnya bukan hanya tanggung jawab pidana yang tetap dibuka kesempatannya untuk diperkarakan, melainkan juga tanggung jawab lainnya, misalnya dibidang administrasi negara. Konsumen yang dirugikan haknya, tidak hanya diwakilkan oleh jaksa dalampenuntutan di peradilan umum untuk kasus pidana, tetapi ia sendiri dapat juga menggugat pihak lain di lingkungan peradilan tata usaha negara jika terdapat sengketa administratif didalamnya, melalui jalur litigasi dan nonlitigasi. 


\section{DAFTAR PUSTAKA}

Alexandra Ide, 2012, Etika dan Hukum dalam Pelayanan Kesehatan, Yogyakarta: Grasia Book Publisher

Wila Chandrawila Supriadi, 2001, Hukum Kedokteran, Banfung: Mandar Maju

Hubert W. Smith, 2008, Kesalahan Dokter atau Tindakan Malpraktik, Jakarta: Penerbit Buku Kedokteran EGC

I Made Pasek Diantha, 2016, Metodologi Penelitian Hukum Normatif dalam Justifikasi Teori Hukum, Jakarta: Prenada Media Grup

R.Soeroso, 1992, Pengantar Ilmu Hukum, Jakarta: Sinar Grafika

Sudikno Martokusumo, 1999, Mengenai Hukum: Suatu Pengantar, Yogyakarta :Liberty,

Wila Chandrawila Supriadi, 2001, Hukum Kedokteran, Bandung: Mandar Maju

Y.A. Triana Ohoiwutun, 2007, Bunga Rampai Hukum Kedokteran Edisi I, Malang: Banyu Media Publishing

\section{Peraturan Perundang-Undangan}

Undang-Undang No. 36 Tahun 2009 tentang Kesehatan ;

Undang-Undang No. 8 Tahun 1999 tentang Perlindungan Konsumen ;

Undang-Undang No. 29 Tahun 2004 tentang Praktik Kedokteran

Keputusan Menteri Kesehatan RI No.756/MEN.KES/SK/VI/2004 tentang Persiapan Liberalisasi Perdagangan dan Jasa di Bidang Kesehatan,

\section{Internet}

Pusat Bahasa Departemen Pendidikan Nasional,http://bahasa.kemdiknas.go.i d/kbbi/index.php 


\section{BIODATA SINGKAT PENULIS}

Sutono Widjaja menyelesaikan pendidikan

Sarjana Hukum pada Fakultas Hukum Universitas Narotama,Surabaya tahun 2018. Saat ini tengah menyelesaikan program Magister Ilmu Hukum di Fakultas Hukum Universitas Narotama, Surabaya. 